\title{
Natural resources for Canterbury agriculture
}

\author{
D.J. MOOT, A. MILLS and K.M. POLLOCK \\ Faculty of Agriculture \& Life Sciences, Lincoln University 7647, Canterbury, New Zealand
}

Derrick.Moot@lincoln.ac.nz

\section{Overview}

On 4 September 2010 a Richter 7.1 earthquake unzipped a $29 \mathrm{~km}$ scarp along the previously unknown "Greendale fault" about $12 \mathrm{~km}$ west of Lincoln. It was a powerful reminder of the dynamic geological forces that have shaped the diverse landscape of Canterbury, which is one of New Zealand's most diverse agricultural regions. For millions of years the Indo-Australian and Pacific Tectonic Plates have collided along the Alpine Fault (McKinnon 1997) to produce the dramatic Southern Alps. These dominate the Canterbury landscape and create the different climates of the east and west coasts of the South Island. Repeated re-working of the land by glacial, alluvial, water, windborne and volcanic activities has resulted in a pedologically young ( $<20000$ years) landscape (O'Connor 1984). Before Polynesian arrival, the region was dominated by forest which was changed by fire to mainly tussock grassland before European settlement in the early 1800 s. Farming in the region commenced during the $1850 \mathrm{~s}$, initially by sheep grazing for wool production on the Canterbury Plains and then the hill and high country followed by arable cropping on the plains in the 1860s (Evans 2004).

The importance of agriculture to the region was reinforced by the establishment of Lincoln College in 1878 , which originally had a dryland farming focus. Its expansion to a University that specialises in all aspects of land management reflects the developing social and technical sophistication of the region and its people. Climatically, the low annual rainfall $(650 \mathrm{~mm})$ and warm föhn north-west winds mean the provision of stock and irrigation water is essential for intensive agriculture. Water from the mountain-fed rivers or deep alluvial aquifers can treble the productive capacity of the dryland farms and $70 \%$ of New Zealand's water use for irrigation is in the region. Such intensification inevitably produces changes of land use, is associated with greater inputs of inorganic fertilisers and other agrichemicals, and can lead to environmental degradation. Tension between the growing urban and diminishing rural populations is centred especially on the ownership and use of the region's water resources. The national significance of this was highlighted recently when the government dismissed the region's elected Councillors and replaced them with appointed Commissioners. They now oversee all of the Canterbury Regional Council's functions, with a strong directive to "deal with water issues". In parallel, a major focus of the local scientific community is to assist the management of agricultural intensification along ecologically acceptable principles. Since 1990 there has been a rapid expansion of irrigation associated with the conversion of dryland sheep and forestry land to large-scale dairy farming. Water and nitrogen management, winter grazing systems, and integrated farm management are all at the forefront of research and policy questions.

The expansion of dairying has also challenged sheep, beef and deer production to intensify on more difficult hill and high country areas and put pressure on the traditional integration of store lambs from the hills finished as "Canterbury lamb" on the plains. The evolution of production systems has created a diverse range of more intensive cropping options including cereals, herbage seeds, high value vegetable seeds, forage crops to support the dairy industry, viticulture and horticulture. The complexity of farm businesses and variety of agricultural options available has also generated an experienced commercial agribusiness sector to support farm production, resource and financial management.

Climatically, summer drought is usual and in the future the region is predicted to be warmer and drier (Salinger 2003; Ministry for the Environment 2008) with benefits and opportunities accruing for those with access to irrigation. Conversely, the burnt brown appearance of the foothills and Banks Peninsula may be viewed for longer each summer as the duration and intensity of droughts increases the stress for dryland farmers. Thus, continued pressure to intensify agriculture further on the plains is inevitable. The pace and level of change will depend on how well farmers utilise current and future technologies to mitigate the associated environmental consequences to develop ecologically sustainable and socially acceptable onfarm practices.

\section{Geology}

The Canterbury region accounts for $17 \%$ or $4.53 \mathrm{M}$ ha, of New Zealand's total area (Wilson 2010) with 800 $\mathrm{km}$ of coastline as the eastern boundary. Tectonically mediated mountain building of the Southern Alps, which form the region's western boundary, in 
Table 1 Areas (ha) of cereals (wheat, barley and oats) sown (1999 and 2002) or harvested (2007, 2008 and 2009) and of vegetables (potatoes, green beans and fresh and processed peas) in the Canterbury region. Dash indicates no data (Department of Statistics 2010).

\begin{tabular}{|c|c|c|c|c|c|c|}
\hline Year & Wheat & Barley & Oats & Potatoes & Beans & Peas \\
\hline 1999 & 39512 & 35218 & 5693 & - & - & - \\
\hline 2000 & - & - & - & 4009 & 486 & 4611 \\
\hline 2002 & 35261 & 51567 & 4631 & 4495 & 533 & 4820 \\
\hline 2003 & - & - & - & 4792 & - & - \\
\hline 2007 & 35301 & 36869 & 2925 & 4270 & 537 & 4705 \\
\hline 2008 & 36400 & 45200 & - & - & - & - \\
\hline 2009 & 46900 & 45000 & - & 4340 & - & 3800 \\
\hline
\end{tabular}

combination with glaciations extended the floodplain into the Pacific Ocean where it reached Banks Peninsula. About $63 \%$ of the region's area is classified as mountain and hill country. Inland basins account for $13 \%$ and the volcanically-formed Banks Peninsula represents a further $3 \%$. The coalesced fluvial megafans which formed the Canterbury Plains account for the remaining $21 \%$ of flat to gently undulating land. The plains are about $185 \mathrm{~km}$ long and up to $70 \mathrm{~km}$ wide, and rise gradually from the coast to $\sim 300 \mathrm{~m}$ above sea level (a.s.1.) at the foothills (Leckie 2003).

The peaks in the Southern Alps increase in height by $\sim 10 \mathrm{~mm} / \mathrm{yr}$ (Tippett \& Kamp 1995) and include 19 mountains over $3000 \mathrm{~m}$ a.s.1.. They feed water from glacial ice, snow melt and rainfall into fast flowing, predominantly braided river systems which flow across the alluvial floodplains. The four main mountainfed rivers are the Waimakariri, Rakaia, Rangitata and Waitaki. Canterbury's rivers carry a sediment load that is over 10 times the global average (Griffiths \& Glassby 1985). Erosion from the western regional boundary is due to tectonic building and the subsequent rapid alluvial transport of sediment down the rivers. In eastern regions, such as near Ashburton, coastal erosion occurs at up to $1 \mathrm{~m} / \mathrm{yr}$ (Gibb 1978), while the central areas are considered more stable (Leckie 1994).

\section{Soils}

In their native state the overlying soils are slightly to moderately acidic ( $\mathrm{pH} 4.5-5.5)$ with low levels of $\mathrm{N}, \mathrm{P}$ and $\mathrm{S}$ and several key micronutrients including $\mathrm{B}, \mathrm{Co}$, $\mathrm{Cu}$, Se, I and Mo (Kemp et al. 1999). Brown, pallic and gley soils are dominant in the region. In the hill and high country these soils, formed under medium-high rainfalls, are free-draining with brown colours due to iron oxide coatings and pallic soils are poorly drained soils formed in low rainfall, summer-dry environments. Gley soils are exposed to periodic water-logging which causes anaerobic and reducing conditions. The brown soil group can be separated into two subgroups. The stony subgroup accounts for what are commonly referred to as "light soils". These stony and/or shallow soils account for $\sim 465400$ ha of land on the plains (Taylor 1967). Their potential for crop, horticultural or pastoral use is restricted by their low water holding capacity in addition to temporal and spatial variability of rainfall. On the floodplains, soil depth to gravels can vary over small $(5.0 \mathrm{~m})$ distances. This reflects the underlying effect of previous river channels and river banks which have dissected the plains. Many plains soils hold between 60 and $90 \mathrm{~mm} / \mathrm{m}$ (Morgan et al. 2002) of plant available water content (PAWC) but are $<0.5 \mathrm{~m}$ deep. Rainfall in excess of storage capability, regardless of its timing, is therefore drained to groundwater or enters waterways through overland flow. These shallow soils have been favoured for recent conversion to dairy farming because of their low risk of pugging damage. However, they require careful irrigation management, with frequent small applications of water, to minimise the risk of drainage and associated leaching of nutrients. Deeper, well-drained soils may hold $150 \mathrm{~mm} / \mathrm{m}$ and be over $2.0 \mathrm{~m}$ in depth giving $>300 \mathrm{~mm}$ of PAWC (Brown et al. 2003) and are often used for high-value cropping.

$\mathrm{P}$ and S-based fertilisers with Mo and/or lime are used widely in all pastoral ecosystems (flat, rolling, hill, high country) to enable biological $\mathrm{N}$ fixation by pastoral legumes. Use of inorganic $\mathrm{N}$ fertiliser has increased over time, predominantly in dairy systems on the plains, to meet the increased demand for feed on the shoulders of the milking season in autumn and early spring. The majority of pastoral topsoils are high (3$10 \%)$ in organic matter and it increases with time under pasture provided soil moisture is adequate (Haynes \& Williams 1993).

\section{Climate}

The South Island's climate is dominated by high pressure systems that approach from the west across the Tasman Sea. In Canterbury, they bring settled weather conditions with periods of strong drying northwest winds and mean summertime potential evapotranspiration (PET) rates of 4-6 $\mathrm{mm} / \mathrm{d}$. Near the coast and inland from Banks Peninsula, northeast winds prevail (McKendry 1983). Low pressure troughs 
Table 2 Area (ha) sown for seed production of the seven main herbage species grown for seed in five seasons. Data from Foundation for Arable Research.

\begin{tabular}{|c|c|c|c|c|c|}
\hline Species & $1995 / 96$ & $1999 / 00$ & $2004 / 05$ & $2008 / 09$ & $2008 / 09$ \\
\hline Perennial ryegrass & 10950 & 15035 & 11915 & 14465 & 11050 \\
\hline Italian ryegrass & 3070 & 2460 & 6260 & 5535 & 6510 \\
\hline Hybrid ryegrass & 1140 & 2010 & 2640 & 1625 & 1725 \\
\hline Tall fescue & 197 & 1030 & 1030 & 749 & 576 \\
\hline Cocksfoot & 1175 & 348 & 668 & 958 & 1080 \\
\hline White clover & 13915 & 10055 & 8340 & 5915 & 8420 \\
\hline Red clover & 1130 & 1270 & 579 & 380 & 413 \\
\hline
\end{tabular}

Figure 1 Changes in the number (millions) of (a) beef and dairy cattle and deer and (b) sheep (rams, ewes and wethers) and lambs in Canterbury between 1990 and 2009 (Department of Statistics 2010).

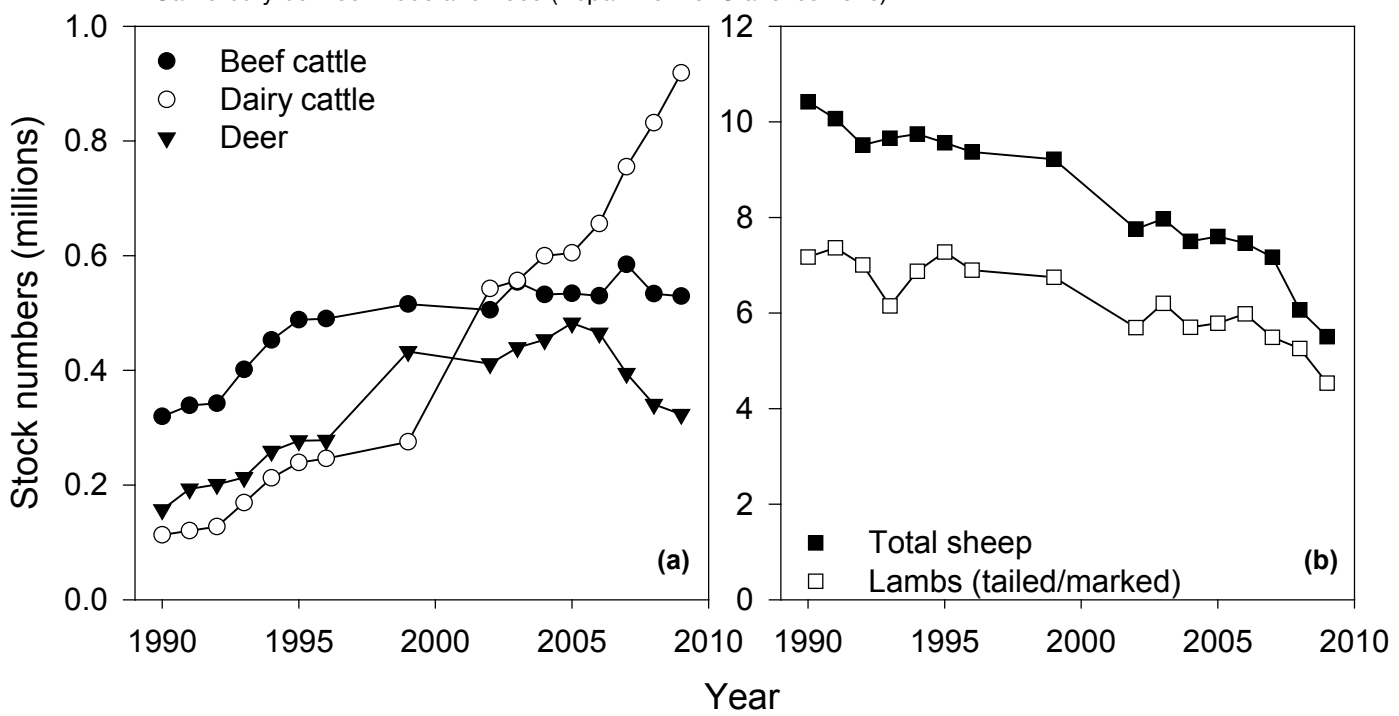

(depressions) of varying strength also move across the country from the west. In winter months these depressions, on passing to the east, can bring rain, sleet and snow, with the snow occasionally settling at sea level. The Southern Alps have a major influence on the impact of these systems including the amount and location of consequent precipitation.

There is a strong rainfall gradient from west to east across the plains with $>1000 \mathrm{~mm}$ on the western foothills on the eastern side of the Southern Alps and $\sim 600 \mathrm{~mm}$ on the eastern seaboard (Morgan et al. 2002; NIWA 2010a). In most locations rainfall is distributed evenly throughout the year, on average, but in eastern areas it is well short of PET demand, so there are regular summer soil water deficits. These restrict pasture and crop growth between October and March (NIWA 2010a). Salinger (2003) summarised the current climate using Ashburton as typical of dryland Canterbury. Long-term weather records (1930-2002) give a mean potential soil moisture deficit (PMSD) of $325 \mathrm{~mm}$ with a range from 120 to $>560 \mathrm{~mm}$. A significant PSMD of $\geq 100 \mathrm{~mm}$ was found to occur by 1 December in $50 \%$ of years and by 1 January in $70 \%$ of years. Mean daily total solar radiation is $22.5 \mathrm{MJ} /$ $\mathrm{m}^{2} / \mathrm{d}$ in mid-summer when daily mean air temperature is above $16^{\circ} \mathrm{C}$, but it declines to $4.4 \mathrm{MJ} / \mathrm{m}^{2} / \mathrm{d}$ in midwinter when frequent ground frosts and daylength of 9 $\mathrm{h}$ reduce the daily mean air temperature to $6.1^{\circ} \mathrm{C}$.

\section{Land use}

The indigenous ecosystems of the lowland plains contained kanuka (Kunzea ericoides) shrubland (Molloy \& Ives 1972) which regenerated freely after periodic fires before and after Polynesian colonisation 1 000 years ago (McGlone 1989). At higher altitudes fescue tussock (Festuca novae-zelandiae) with clumps of matagouri (Discaria toumatou) or native broom (Camichaelia sps) and Danthonia (Rytidosperma clavatum) grassland dominated. The expansion of agriculture means remnants of these native sites are 
Figure 2 Cumulative probabilities of mean seasonal temperatures* for 1970-2010, solid line, and broken lines for future scenarios based on data from Wratt et al. (2004) including 2030 low temperature rise, 2030 high temperature rise and 2080 high temperature rise for Canterbury. Horizontal broken lines indicate the median temperatures where they intersect the curves ${ }^{*}$ temperature data from Lincoln-Broadfields climate records, NIWA 2010b).
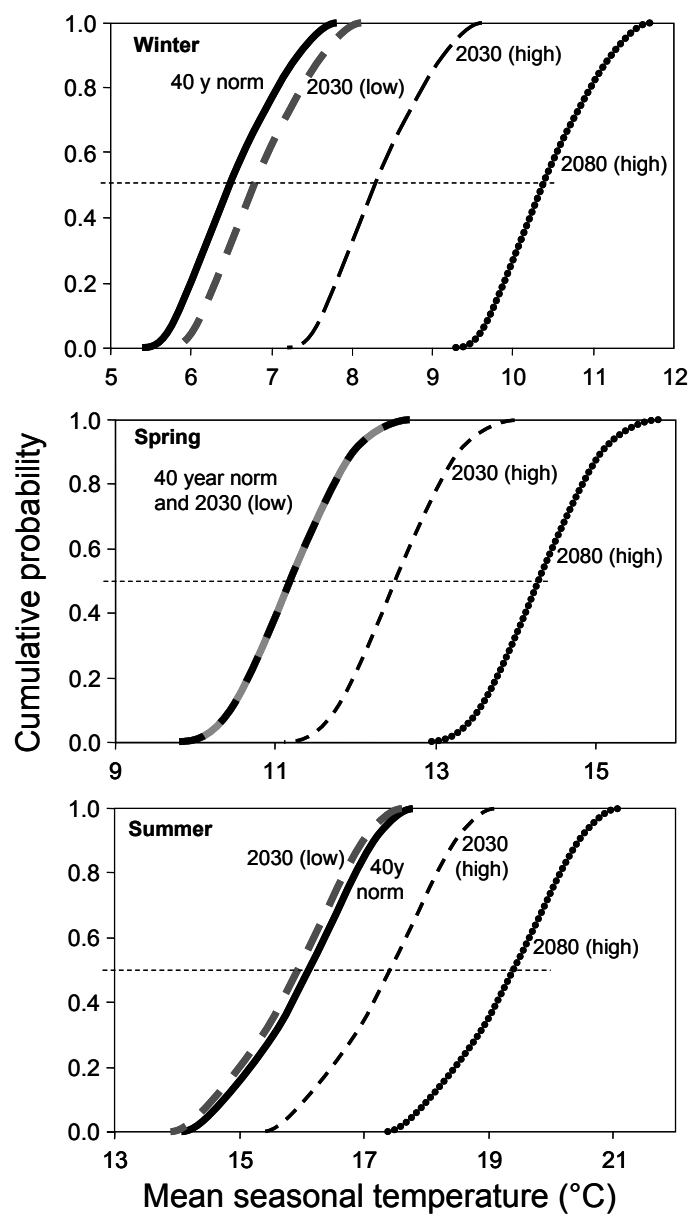

rare.

The addition of fertility and grazing along with the soil, climate and water resources now support diverse farm types. Wheat and barley are produced on up to 100000 ha (Table 1) for local human and livestock consumption with limited opportunity for export. The favourable climate enables potential yields of over $15 \mathrm{t} / \mathrm{ha}$ for wheat and $13 \mathrm{t} / \mathrm{ha}$ for barley, with mean district yields between 5.2 and $12.7 \mathrm{t} / \mathrm{ha}$ depending on input levels (Foundation for Arable Research). Seed production of herbage grasses covers $\sim 15000$ ha (Table 2) with variable yields that may exceed 2.5 $\mathrm{t}$ seed/ha. Red and white clovers for seed production
Figure 3 Thermal time $\left({ }^{\circ} \mathrm{Cd}\right.$, base temperature $\left.3^{\circ} \mathrm{C}\right)$ or heat accumulation from 1 July for Lincoln 2000, 2080 and Napier 2000, and from 1 November for Lincoln 2000 and 2080. (Air temperature data from NIWA CliFlo climate database, NIWA 2010b; projected temperature increases from Wratt et al. 2004).

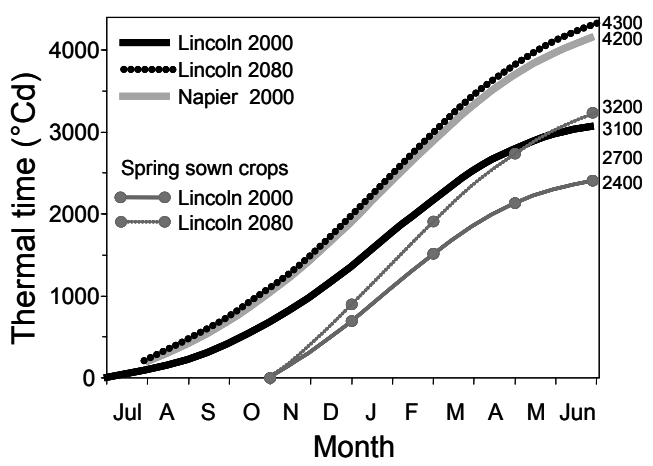

cover $\sim 10000$ ha annually with yields of up to $1.5 \mathrm{t}$ seed/ha (Mather et al. 1995). High value, specialist vegetable and brassica seed production has increased over the last 15 years, much for northern hemisphere markets. Some of these seed crops provide high quality feed for lamb finishing and now arable farmers may also grow pasture and crop-based forages that support dairy operations in summer or winter. Animals are commonly wintered on shallow, stony soils where they primarily break-fed brassica crops or ryegrass and cereal greenfeeds supplemented by crop residues and silage (maize, cereal and pasture). Cropping farmers have some annual flexibility in the mix of crops sown, but strict quarantine and certification requirements limit some options and future land use. Fresh vegetable production occurs on the outskirts of Christchurch, and there is also an expanding processed vegetable industry. Canterbury has $60-70 \%$ of the total national area of green beans, $\sim 60 \%$ of the fresh and processed peas and $30-40 \%$ of the potatoes. Processed potato production is increasing mainly to supply growing markets in Asia. There are also large areas of onions grown for export and viticulture is centred in north Canterbury.

The mountainous high country is home to fine wool merino sheep with deer numbers waxing and waning (Fig. 1a) in response to price signals. On the region's foothills and Banks Peninsula breeding ewes with store lambs dominate and beef cows assist to maintain pasture quality and diversify farm income. Livestock numbers over the last 20 years reflect the rapid reduction in breeding ewe flocks displaced by an extra 800000 dairy cows. There were over $10 \mathrm{M}$ sheep in Canterbury in 1990 but this has declined almost linearly to $5.5 \mathrm{M}$ by 2009 (Fig. 1b). Since 2005 the area of plantation forest has decreased by about $12 \%$ to 109800 ha (Forestry Owners Association and MAF 2010) with most 
converted to pasture in response to government policy and changing commodity prices.

For pastoral farmers, traditional ryegrass (Lolium perenne) and white clover (Trifolium repens) dominate where irrigation or adequate rainfall $(>800 \mathrm{~mm})$ is available with average yields of 12-15 t DM/ha. In dryland areas, cocksfoot (Dactylis glomerata), tall fescue (Festuca arundinacea) or Bromus spp. are the main grass species sown in a mix that could include subterranean clover (Trifolium subterraneaum), chicory (Cichorium intybus) or plantain (Plantago lanceolata) to produce 6.0-8.0 t DM/ha. Lucerne (Medicago sativa) is returning to the plains for grazing by sheep, beef cattle or deer and to be conserved for use as a supplementary feed in all livestock operations.

\section{Irrigation}

Irrigation development has occurred steadily in Canterbury since the early $20^{\text {th }}$ century. However, there has been a dramatic expansion recently because irrigation is essential for intensive dairy production, especially to guarantee pasture growth in the usual dry period from late spring to autumn. In the recent expansion, modern centre-pivot and lateral-spray irrigation technology have replaced old border-dyke systems and have also extended onto large areas of previously unirrigated land. The demand for irrigation water continues to increase and already covers an estimated 364000 ha in Canterbury which represents $\sim 70 \%$ of the nation's irrigated land (National Infrastructure Unit 2010). With competing stakeholders, the allocation and use of water is currently the most contentious issue facing agriculture and society in general. To address this, the Canterbury Water Management Strategy (CWMS) was implemented. The Stage 1 report dealt with water quantity matters (Morgan et al. 2002) and concluded that, with development of storage to capture water during periods of high flows from Canterbury's large alpine rivers, there is sufficient water to meet a likely future demand to irrigate up to $1.0 \mathrm{M}$ ha. This was based on the assumption that $\sim 90 \%$ of the demand for water would be from irrigation and that some redistribution would be required to alleviate over-allocation pressure on the region's smaller lowland streams. The Stage 2 report (Dark et al. 2009) was then commissioned to examine the possibility of meeting irrigation, social and environmental aims through different water storage options. It concluded that suitable storage sites were the scarcest resources and the current $a d$ hoc approach to water development was an inefficient method to maximise stakeholder acceptance and infrastructure development.

\section{Water quality}

The Stage 3 multi-stakeholder report of the CSWMS (Whitehouse et al. 2007) concluded that rigorous scientific and public consideration was required of 1) the impacts of land use intensification and its effects on water quality, 2) mitigation and management systems for water quality, and 3) methods for maintaining or improving flow variability and low flows in major rivers. Many lowland rivers and streams now disappear completely each summer due to changes in weather patterns and water use. Further studies have subsequently investigated storage options in detail (Dark et al. 2009), assessed the effects of rural land use on water quality (Davies-Colley et al. 2003) and examined impacts of nitrate discharge to groundwater. In summary, pastoral land use is highlighted as having the greatest impact on water quality through 1) decreased visual quality from the displacement of fine sediments into waterways, 2) nutrient ( $\mathrm{N}$ and $\mathrm{P}$ ) application being beneficial to productivity on land but causing eutrophication and largely negative impacts for waterways and 3) microbes from faecal contamination directly affecting untreated drinking water. An initial assessment (Bidwell et al. 2009) of nitrate discharge from agricultural land indicates that there is potential for concentrations in shallow $(<20 \mathrm{~m})$ groundwater to exceed safe drinking water standards. They suggest that due to the contribution of low-nitrate river recharge to the groundwater beneath the plains, groundwater quality generally improves with depth. This means high quality drinking water is expected to be attainable almost anywhere on the plains, although the depth to it will differ at a local level. Furthermore, average nitrate concentrations from some agricultural land uses are higher than allowable indicating a mix of land uses is desirable.

To mitigate the impacts of rural land use on water quality two broad strategies have been recommended (Davies-Colley et al. 2003). The first is to reduce pollution at the source and will require on-farm adoption of available technologies. These include matching fertiliser demand to crop and pasture requirements, which has been aided by the provision of decision support systems such as 'Sirius' (Jamieson et al. 1998). Recommendations are to avoid grazing in periods of water-logging and wet weather to minimise nitrate leaching and run-off, particularly on shallow soils. For dairy systems, this may require changes in grazing management, particularly on winter feed crops, greater use of stand off pads or development of shelters for indoor feeding. Nitrification inhibitors have been shown to reduce greenhouse gas emissions and nitrate leaching (Di et al. 2007; Di et al. 2009) from dairy farms but debate over their impact on pasture production appears to have limited uptake by the industry. Irrigation 
calculators have also been developed. They are increasingly used by arable farmers but their current uptake by pastoral farmers is low. The second strategy focuses on interception of pollutants on land by fencing rivers and streams, and riparian planting to create a buffer zone that can trap pollutants, before they enter the waterways.

\section{Climate change}

For Canterbury, climate change scenarios for the future indicate that the prevailing westerly circulation is likely to strengthen bringing warmer and drier conditions on the plains (Wratt et al. 2004). A warming of $0.2-1.4^{\circ} \mathrm{C}$, relative to 1990 , is likely by 2030 and $0.5-3.4^{\circ} \mathrm{C}$ by 2080. The warming is expected to be greatest in winter and accompanied by an average annual reduction in precipitation of $10 \%$.

Fig. 2 shows how we might experience future temperatures compared with recent seasonal means and probabilities of departures from the median temperatures. For example, winter temperatures, even with the low temperature rise estimate for 2030, are expected to exceed the recent winter means for about $65 \%$ of the time. For the 2030 high temperature scenario the coolest winter in future may be warmer than the recent means. By 2080 the lowest winter temperatures could exceed the highest temperatures currently experienced. The contrasts are not as large for spring or summer but the milder winter temperatures will enable crops and pastures to be grown earlier in the year with significantly increased winter and annual forage growth possible in coastal and low inland Canterbury. The curves in Fig. 2 assume the same frequency distribution of temperature means for the future as calculated for the present. However, Wratt et al. (2004) recognise that climate warming will also result in more variability in the temperature extremes which would stretch the range of temperatures experienced for future scenarios.

Warmer temperatures will mean more rapid heat accumulation than at present (Fig. 3) with faster plant growth, shortened times between physiological stages and earlier crop maturity, provided water is not limiting. By 2080 Canterbury could experience a temperature profile similar to that of Napier now. This also means that fewer spring frosts could allow earlier sowing of crops such as maize that would benefit from the warmer climate. Warmer, drier late summer conditions also provide ideal conditions for combine harvesting, so lower crop losses and less sprouting, staining, bleaching of seed can be expected to improve seed quality.

Accompanying these changes in mean temperature and annual rainfall, scenarios also suggest potentially greater changes in the extremes. Sensitivity analyses based on high greenhouse gas emission scenarios predict a decrease in the number of frosts by $50 \%$ but 25 more days with temperatures above $25^{\circ} \mathrm{C}$. These changes will affect pasture and crop water requirements with an increased occurrence of 1 in 20 year droughts to 1 in 5 years by the 2080s (Mullan et al. 2005) and an increase in PSMD of $90 \mathrm{~mm}$ (Salinger 2003). Managing additional background variability induced by interdecadal oscillations, El Niño and La Niña, will add complexity to dryland farming and increase the pressure on irrigation systems. Potential ET deficit (PED) is a suitable indicator of the amount of water required in addition to rainfall to grow pastures or crops without drought stress. As for temperature (Fig. 2) the median and frequency distribution of PED values for a season will increase and by 2080 the median PED could be as high as any experienced in the last 40 years (Fig. 4).

Taking climate change scenarios and looking at the implications for pasture production highlights the expected differences for dryland and irrigated situations. Grass-based pastures fully supplied with water and $\mathrm{N}$ can yield over $20 \mathrm{t} \mathrm{DM} /$ ha per year (Mills et al. 2006). A simple addition of growth provided by the warmer temperatures leads to an estimate that

Figure 4 Cumulative probabilities of potential evapotranspiration deficit (PED, mm) for 19702010, solid line, and broken lines for future scenarios based on data from Mullan et al. (2005) including 2030 low increase in PED, 2030 high increase and 2080 high increase in PED for Canterbury. Horizontal broken line indicates the median PED where it intersects the curves.

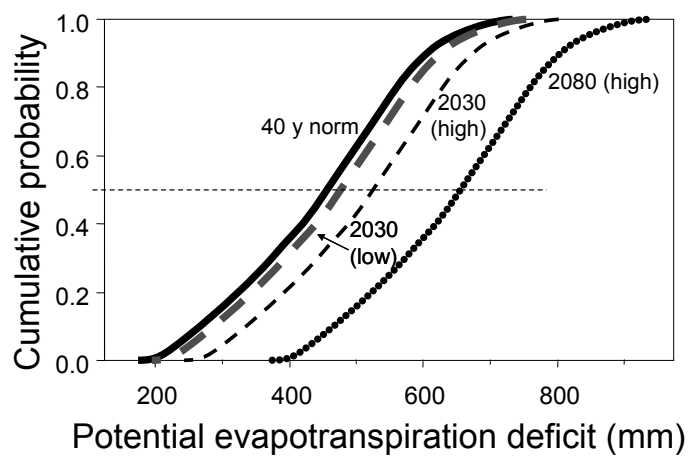

potential production could increase to $\sim 30 \mathrm{t} \mathrm{DM} / \mathrm{ha}$ (Fig. 5). However, this is unlikely to be obtained with temperate grass-based pastures due to $\mathrm{N}$ deficiency and hot temperatures restricting their growth. The predicted $\mathrm{N}$ requirement, from all sources (soil and fertiliser), to achieve such a yield is $\sim 1000 \mathrm{~kg} \mathrm{~N} / \mathrm{ha} / \mathrm{yr}$. This is based on a critical $\mathrm{N}$ concentration of $3.3 \%$ required for nonlimited growth to $3.0 \mathrm{t} \mathrm{DM} / \mathrm{ha}$ and 10 harvests/yr (Mills et al. 2009). Similar amounts of $\mathrm{N}$ are returned to the 
Figure 5 Accumulated cocksfoot yield, determined with non-limiting amounts of water and supplied with either non-limiting or nil $\mathrm{N}$ fertiliser (Mills et al. 2006). The solid line is the estimated potential yield based on thermal time calculated using mean monthly air temperatures at Lincoln (Broadfields Meteorological station, 1975-2005) and a nonlimited growth rate of $7.2 \mathrm{~kg} \mathrm{DM} / \mathrm{ha} /{ }^{\circ} \mathrm{Cd}$ or $3.2 \mathrm{~kg}$ $\mathrm{DM} / \mathrm{ha} /{ }^{\circ} \mathrm{Cd}$ in the $\mathrm{N}$ deficient pasture above a base air temperature of $3^{\circ} \mathrm{C}$. The broken lines indicate the yield expected under climate change scenarios (Wratt et al. 2004).

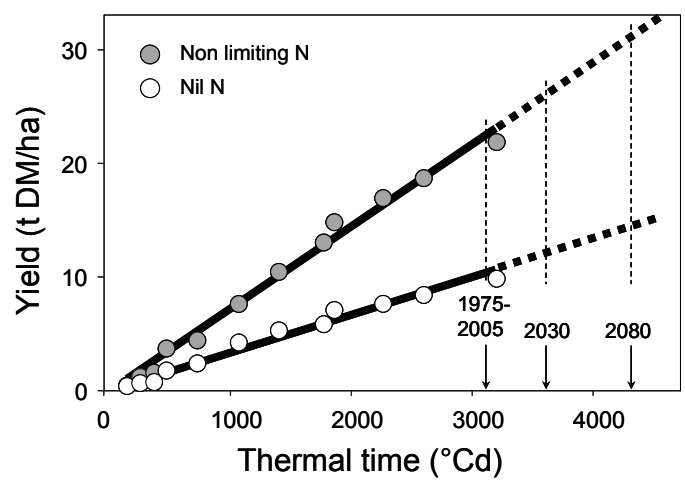

soil in a urine patch by dairy cows. However, it would be risky and inadvisable to apply $\mathrm{N}$ fertiliser at the high rates needed to top up the $\mathrm{N}$ contributed from the soil and via animal returns to maintain maximum pasture growth rates.

A similar temperature scenario for dryland pasture induces an extended period of drought in mid-summer. A dryland cocksfoot pasture with no fertiliser $\mathrm{N}$ produced only $7.5 \mathrm{t} \mathrm{DM} / \mathrm{ha} / \mathrm{yr}$ in response to a summer drought of 75 days and a thermal time of $3100^{\circ} \mathrm{Cd}$ (Fig. 6). Scenarios for 2030 and 2080 show there is no growth during an extended summer drought and that the autumn growth is constrained by the mean annual thermal time accumulation of 3600 and $4300^{\circ} \mathrm{Cd}$ for 2030 and 2080 , respectively. This produces about $7.5 \mathrm{t} \mathrm{DM} /$ ha across all scenarios. This assumes that the 'average' drought for each scenario starts at about $1340^{\circ} \mathrm{Cd}$ and that full growth rate of $3.2 \mathrm{~kg} \mathrm{DM} / \mathrm{ha} /{ }^{\circ} \mathrm{Cd}$ resumes immediately at the end of the drought. Moot et al. (2008) noted the recovery to full potential growth rate can be delayed for several weeks while the canopy regenerates thus the effect of drought can, and does, last longer than the actual period of drought. For crops, Jamieson \& Cloughley (2001) ran several scenarios and predicted early maturity of winter and spring wheat crops but an increase in yield due to the additional fertilisation effect of increased $\mathrm{CO}_{2}$. Predictions for horticulture and viticulture are also positive provided there is adequate control of pests and diseases.
Figure 6 Effect of summer drought on cocksfoot grown without fertiliser $\mathrm{N}$ for current (75 d of drought) and future scenarios of 90 and $121 \mathrm{~d}$ of drought. A regression line through circles represents growth of $3.2 \mathrm{~kg} \mathrm{DM} / \mathrm{ha} /{ }^{\circ} \mathrm{Cd}$, accumulated above a base air temperature of $3^{\circ} \mathrm{C}$, under $\mathrm{N}$ deficient and nonlimiting water conditions (Mills et al. 2006). It is assumed the growth rate returns to $3.2 \mathrm{~kg} \mathrm{DM} /$ $\mathrm{ha} /{ }^{\circ} \mathrm{Cd}$ at the end of drought period.

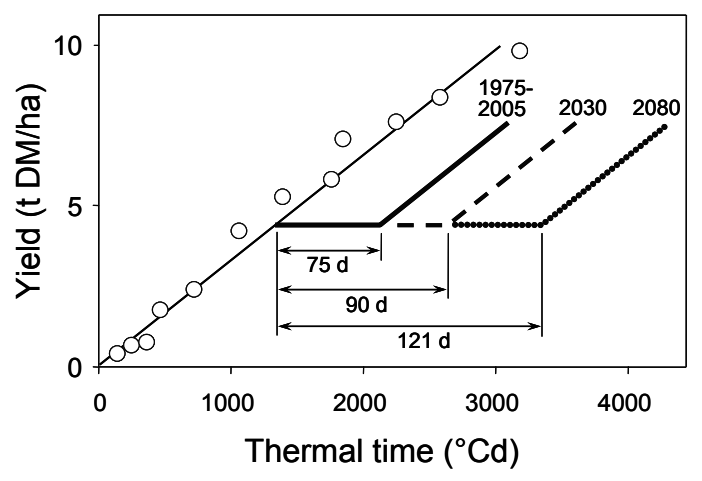

\section{Conclusions}

The natural resources of Canterbury have been developed and have contributed to the economic and social prosperity of the region largely through the utilisation of water and intensification of agricultural production. The recent dairying phenomenon has resulted from compelling economic drivers that have enabled rapid expansion of irrigation to overcome the constraints of low water holding capacity of soils and hot dry summers. International experience, for example in California and Spain, suggests the diversity of land use on the plains is likely to increase along with the development of irrigation. In particular, plant-based food production that uses water more efficiently, and poses less risk of adverse environmental impacts, is likely to displace intensive pastoral agriculture in the long-term. This change will be driven by increased temperatures associated with climate change, greater competition for scarce water resources as its value increases and competition from alternative land uses to dairying as economic drivers change. On the hills and in the high country more extensive livestock production is expected to remain but alternative plant species, management strategies and livestock classes are required to cope with the diversity of soil types and impacts of climate change.

\section{ACKNOWLEDGEMENTS}

Drs Derek Wilson, Jim Moir, Warwick Scott, Vince Bidwell and Mr Dick Lucas for comments on this manuscript. Lincoln University, the Foundation for Arable Research (FAR) for the herbage seed production data. Beef + Lamb New Zealand through the Foundation 
for Research, Science and Technology, Pastoral 21 Feed programme.

\section{REFERENCES}

Bidwell, V.; Lilburne, L.; Thorley, M.; Scott, D. 2009. Nitrate discharge to groundwater from agricultural land use: An initial assessment for the Canterbury Plains. Report prepared by Lincoln Ventures Limited, Landcare Research, and Environment Canterbury. 16 pp.

Brown, H.E.; Moot, D.J.; Pollock, K.M. 2003. Long term growth rates and water extraction patterns of dryland chicory, lucerne and red clover. Legumes for Dryland Pastures. Grassland Research and Practice Series 11: 91-99.

Dark, A.; Bright, J.; Sigle, S. 2009. Canterbury Strategic Water Study (Stage 2). Report prepared for the Canterbury Mayoral Focum by Aqualink Research Ltd. Christchurch: Environment Canterbury (ECAN).

Davies-Colley, R.; Cameron, K.C.; Francis, G.S.; Bidwell, V.; Ball, A.; Pang, L. 2003. Effects of Rural Land Use on Water Quality: NIWA; Ministry for the Environment. Accessed: 29/9/2010. http://www. canterburywater.org.nz/downloads/stakeholders/ 11c-Pages-cover-1-19-9-28-Effects-of-rural-landuse-on-.pdf.

Department of Statistics. 2010. Agriculture Variable by Regional Council for 1999, 2002, 2007, 2008 and 2009. Accessed: 24/9/2010. http://www.stats.govt.nz/ infoshare/ ViewTable.aspx?pxID=26fc4a72-03324600-b52f-986a9857f17a.

Di, H.J.; Cameron, K.C.; Shen, J.P.; He, J.Z.; Winefield, C.S. 2009. A lysimeter study of nitrate leaching from grazed grassland as affected by a nitrification inhibitor, dicyandiamide, and relationships with ammonia oxidizing bacteria and archaea. Soil Use and Management 25: 454-461.

Di, H.J.; Cameron, K.C.; Sherlock, R.R. 2007. Comparison of the effectiveness of a nitrification inhibitor, dicyandiamide, in reducing nitrous oxide emissions in four different soils under different climatic and management conditions. Soil Use and Management 23: 1-9.

Evans, R.N. 2004. Introduction to farming in the Central Canterbury area. Proceedings of the New Zealand Grassland Association 66: 5-9.

Forestry Owners Association; MAF. 2010. New Zealand Plantation Forestry Industry Facts and Figures. Accessed: 1/10/2010. http://www.nzfoa.org. nz/ publications/facts-and-figures.

Gibb, J.G. 1978. Rates of coastal erosion and accretion in New Zealand. New Zealand Journal of Marine and Freshwater Research 12: 429-456.

Griffiths, G.A.; Glassby, G. 1985. Input of river-derived sediment to the New Zealand continental shelf. Estuarine, Coastal and Shelf Science 21: 773-787.

Haynes, R.J.; Williams, P.H. 1993. Nutrient cycling and soil fertility in the grazed pasture ecosystem. Advances in Agronomy 49: 119-199.

Jamieson, P.D.; Cloughley, C.G. 2001. Impacts of climate change on wheat production. pp. 57-63. In: The effects of climate change and variation in New Zealand. An assessment using the CLIMPACTS system. Eds. Warrick, R.A.;. Kenny, G.J; Harman, J.J. International Global Change Institute (IGCI) \& University of Waikato, Hamilton.

Jamieson, P.D.; Semenov, M.A.; Brooking, I.R.; Francis, G.S. 1998. Sirius: a mechanistic model of wheat response to environmental variation. European Journal of Agronomy 8: 161-179.

Kemp, P.D.; Condron, L.M.; Matthew, C. 1999. Pastures and Soil Fertility. pp. 67-82. In: New Zealand Pasture and Crop Science. Eds. White, J.; Hodgson, J. Oxford University Press, Auckland.

Larsen, S.H. 2005. Evaluation of Drought at Lincoln, Canterbury. Report No. R05/29. Environment Canterbury (ECAN); Christchurch. 58 pp.

Leckie, D.A. 1994. Canterbury Plains, New Zealand - implications for sequence stratigraphic models. American Association of Petroleum Geologists Bulletin 78: 1240-1256.

Leckie, D.A. 2003. Modern environments of the Canterbury Plains and adjacent offshore areas, New Zealand - an analog for the ancient conglomeratic depositional systems in nonmarine and coastal zone settings. Bulletin of Canadian Petroleum Geology 51: 389-425.

Mather, R.D.J.; Melhuish, D.T.; Herlihy, M. 1995. Trends in the global marketing of white clover cultivars. White Clover: New Zealand's Competitive Edge. Agronomy Society of New Zealand Special Publication 11/Grassland Research and Practice Series 6: 7-14.

McGlone, M.S. 1989, The Polynesian settlement of New Zealand in relation to environmental and biotic changes. New Zealand Journal of Ecology 12: 115129.

McKendry, I.G. 1983. Spatial and temporal aspects of the surface wind regime on the Canterbury Plains, New Zealand. Journal of Climatology 3: 155-166.

McKinnon, M. (Ed.). 1997. Bateman New Zealand Historical Atlas: ko papatuanuku e takoto nei. David Bateman in association with Historical Branch, Department of Internal Affairs, Auckland. 290 pp.

Mills, A.; Moot, D.J.; Jamieson, P.D. 2009. Quantifying the effect of nitrogen of productivity of cocksfoot (Dactylis glomerata L.) pastures. European Journal of Agronomy 30: 63-69. 
Mills, A.; Moot, D.J.; McKenzie, B.A. 2006. Cocksfoot pasture production in relation to environmental variables. Proceedings of the New Zealand Grassland Association 68: 89-94.

Ministry for the Environment. 2008. Climate Change Effects and Impacts Assessment: A Guidance Manual for Local Government in New Zealand ( $2^{\text {nd }}$ ed.). Mullan, B.; Wratt, D.; Dean, S.; Hollis, M.; Allan, S.; Williams, T.; Kenny, G.; MfE. Ministry for the Environment, Wellington. Accessed: 29/9/09. http:// www.mfe.govt.nz/publications/ climate/climatechange-effect-impacts-assessments-may08/climatechange-effect-impacts-assessment-may08.pdf.

Molloy, B.P.J.; Ives, D.W. 1972. Biological reserves of New Zealand, 1. Eyrewell Scientific Reserve, Canterbury. New Zealand Journal of Botany 10: 673700.

Moot, D.J.; Brown, H.E.; Pollock, K.M.; Mills, A. 2008. Yield and water use of temperate pastures in summer dry environments. Proceedings of the New Zealand Grassland Association 70: 51-57.

Morgan, M.; Bidwell, V.; Bright, J.; McIndoe, I.; Robb, C. 2002. Canterbury Strategic Water Study. Report to Ministry of Agriculture \& Forestry (MAF), Environment Canterbury (ECan) and Ministry for the Environment (MfE). Report No. 4557/1. Lincoln Environmental, Lincoln. 141 pp.

Mullan, A.B.; Porteous, D.; Wratt, D.; Hollis, M. 2005. Changes in drought risk with climate change. 58 pp. Assessed: 30/9/2010. http://www.mfe.govt.nz/ publications/climate/ drought-risk-may05/droughtrisk-climate-change-may05.pdf.

National Infrastructure Unit. 2010. National Infrastructure Plan. Accessed: 1/10/2010. http://purl. oclc.org/nzt/i-1266.
NIWA. 2010a. Climate Explorer - Canterbury Regional Median Annual Rainfall and Canterbury Regional Median Summer Soil Moisture Deficit Maps. Accessed: 1/10/2010. http://climate-explorer.niwa. co.nz.

NIWA. 2010b. CliFlo - National Climate Database. Accessed: 31/08/10. http://cliflo. niwa.co.nz/.

O'Connor, K.F. 1984. Stability and instability of ecological systems in New Zealand mountains. Mountain Research and Development 4: 15-29.

Salinger, J. 2003. Climate reality - actual and expected. Legumes for Dryland Pastures. Grassland Research and Practice Series 11: 13-18.

Taylor, N.W. 1967. A management study of light land farming in Canterbury, New Zealand. MAgSc thesis, Lincoln University.

Tippett, J.M.; Kamp, P.J.J. 1995. Geomorphic evolution of the Southern Alps, New Zealand. Earth Surface Processes and Landforms 20: 177-192.

Whitehouse, I.; Pearce, A.; McFadden, G. 2007. Final Report prepared on behalf of the Canterbury Mayoral Forum. Canterbury Strategic Water Study (CSWS) Stage 3. Multi-stakeholder evaluation of water storage options. $51 \mathrm{pp}$.

Wilson, J. 2010. Canterbury region - Facts and figures. Te Ara - the Encyclopedia of New Zealand. Accessed: 29/9/2010. http://www.teara.govt.nz/en/canterburyregion $/ 17$.

Wratt, D.S.; Mullan, A.B.; Salinger, M.J.; Allan, S.; Morgan, T.; Kenny, G. 2004. Overview of climate change effects and impacts assessment - A guidance manual for local government. Ministry for the Environment, Wellington. 
